This is a revised personal version of the text of the final journal article, which is made available for scholarly purposes only, in accordance with the journal's author permissions. The full citation is:

Cornell, M., C. J. Banks, and S. Heaven. "Effect of increasing the organic loading rate on the codigestion and mono-digestion of cattle slurry and maize." Water Science \& Technology 66, no. 11 (2012): 2336-2342.

doi:10.2166/wst.2012.459, http://www.iwaponline.com/wst/06611/wst066112336.htm

\title{
Effect of increasing the organic loading rate on the co-digestion and mono-digestion of cattle slurry and maize
}

\author{
M. Cornell*, C.J. Banks** and S. Heaven** \\ * BVdairy, Wincombe Lane, Shaftesbury, Dorset SP7 8QD, UK \\ (E-mail: mariecornell@bvdairy.co.uk) \\ **School of Civil Engineering \& Environment, University of Southampton, Southampton SO17 1BJ, UK \\ (E-mail:cjb@soton.ac.uk)
}

\begin{abstract}
Co-digestion of cattle slurry and maize has been shown to have benefits for both, improving the biogas yield of the slurry and stability of digestion of the maize. The effect of increasing the total loading rate from 3 to $6 \mathrm{~g} \mathrm{VS}^{-1}$ day $^{-1}$ on the co-digestion of cattle slurry and maize, mixed at equal volatile solids volumes, was investigated in laboratory-scale continuously stirred digesters. These were compared to similar digesters evaluating the increase of 1.5 to $3 \mathrm{~g} \mathrm{VS}^{-1}$ day $^{-1}$ loading rates of slurry and maize digested separately. Compared to mono-digestion of the substrates, where the digestion of maize failed at loading rates greater than $2.5 \mathrm{~g} \mathrm{VS}^{-1}$ day $^{-1}$, the co-digestion of cattle slurry and maize was feasible at all the loading rates tested with an increase in the volumetric methane yield occurring with loading rate. Even at the lowest rate of loading the addition of equal amount of volatile solids of maize to slurry lead to an increase in volumetric methane yield of $219 \%$
\end{abstract}

Keywords Anaerobic digestion; cattle slurry; co-digestion; kinetics; maize

\section{INTRODUCTION}

The storage and use of animal wastes of which the EU-27 produces 1284 million tonnes per year (Holm-Nielsen, 2007) leads to the production of greenhouse gases including methane. Anaerobic digestion is a well-established process that can divert the methane released from animal wastes, including cattle slurry, into a source of bio-energy. Bio-energy production is attractive to farmers as it can supply the energy required by the farm and provide an additional source of income; anaerobic digestion also produces a digestate that can be used as fertiliser. Unfortunately, the digestion of cattle slurry alone yields relatively low amounts of bio-energy in comparison to feedstocks such as energy crops (Weiland, 2006). Crop materials such as maize are therefore added to the slurry in order to improve gas production and thus potential income. The digestion of energy crops alone can also be difficult and co-digestion with cattle slurry can improve the buffering capacity of the system, as has been shown for cosubstrates such as fruit and vegetable waste and slaughterhouse waste (Alvarez and Lidén, 2008; Banks et al., 2010) A possible further benefit is the potential for synergy between the co-substrates which some studies have reported (e.g. Machmüller et al., 2007; Cornell et al., 2008). There is little published work on synergy, however, and the effects are often identified through comparison of results from mono- and co-digestion trials following different methodologies, e.g. batch and semi-continuous. This approach may not provide an accurate picture as it has been shown that batch and semi-continuous trials can produce different results (Callaghan et al., 1998 and 1999). 
The effect of increasing the organic loading rate on the co-digestion process has been studied by previous researchers (Alvarez and Lidén, 2008, Lehtomäki et al., 2006, Mähnert and Linke, 2006). In much of the previous work, however, the load increase was achieved by increasing the proportion of one co-substrate, and there is a lack of work investigating the effects of increasing the load while keeping the proportions of the substrates constant. The aim of this study was to identify how increasing the loading rate at a fixed ratio of cattle slurry to maize (Zea mays) ratio affected the biogas production in a long-term trial with continuously-stirred tank reactors (CSTR). To provide a baseline for comparison with the codigestion trials, the impact of increasing the loading rate on the mono-digestion of cattle slurry and maize was also investigated.

\section{MATERIALS AND METHODS}

Feedstocks. Ensiled maize was collected from Downlands and Woolmer farm (Liphook, UK) and cattle slurry from a dairy farm near Southampton (Parkers Farm, Rownhams, UK). Both maize and cattle slurry were finely shredded in a commercial garbage grinder (S52/010 Waste Disposer, Imperial Machine Company Ltd, UK) to remove unwanted material such as stones, which could interfere with the reactor stirring mechanism, and to ensure homogeneity. The maize was then placed in plastic food bags and stored at $-20{ }^{\circ} \mathrm{C}$ and the cattle slurry was stored at $+4{ }^{\circ} \mathrm{C}$, until required.

Twelve continuously-stirred tank reactors (CSTRs) were set up at a temperature of $35 \pm 0.5^{\circ} \mathrm{C}$, maintained by circulating water through an external heating coil around the digesters. Each digester had a total volume of 5 litres with a working volume of 4 litres. The contents of the digester were continuously stirred by means of a motorised asymmetric bar stirrer. Each digester was inoculated with digestate obtained from semi-continuous reactors fed on cattle slurry and maize at an organic loading rate (OLR) of $4 \mathrm{~g} \mathrm{VS}^{-1}$ day $^{-1 .}$ The digesters were run at 'natural' retention times achieved by removing only as much material as was necessary to keep the digester at a constant mass: this ranged from 15 to 29 days for the different OLRs. The digesters were fed daily, with daily removal of excess material. Eight digesters received both cattle slurry and maize while the remaining four digesters were fed on either cattle slurry or maize alone. For the co-digestion study OLRs ranged from 3 to $6 \mathrm{~g} \mathrm{VS}^{-1}$ day $^{-1}$ with each component supplying $50 \%$ of the load on a VS basis (Table 1). The OLRs in the monodigestion trial were in the range 1.5 to $3.0 \mathrm{~g} \mathrm{VS} \mathrm{l}^{-1} \mathrm{day}^{-1}$, with increments occurring once each pair showed stabilisation. Retention times were made to match those of the co-digestion trial by the addition of tap water containing $1 \mathrm{mg} \mathrm{l}^{-1}$ trace element solution (Gonzalez-Gil et al., 2001) (Table 1).

The digesters were connected to tipping-bucket gas counters logged at 10-minute intervals, with gas volumes calculated and reported at $101.325 \mathrm{kPa}$ and $0^{\circ} \mathrm{C}$, as described in Walker et al. (2009). Gas composition was determined on a weekly basis using a Varian CP 3800 gas chromatograph (Varian USA) with Argon as the carrier gas at a flow of $50 \mathrm{ml} \mathrm{min}{ }^{-1}$. The GC was fitted with a Hayesep C column and a molecular sieve $13 \times(80-100$ mesh) operated at a temperature of $50{ }^{\circ} \mathrm{C}$. Weekly samples were taken for determination of total solids (TS) and volatile solids (VS) according to standard method $2540 \mathrm{G}$ (APHA, 2005). Total Kjeldahl Nitrogen (TKN) and ammonia were determined using a Kjeltech block digestion and steam distillation unit according to the manufacturer's instructions (Foss Ltd, Warrington, UK). Volatile fatty acids (VFA) were measured by gas chromatography (Shimazdu 2010). Alkalinity was measured weekly by titration with $0.25 \mathrm{~N} \mathrm{H}_{2} \mathrm{SO}_{4}$ to endpoints of 5.7, 4.3 and 4.0 representing partial (PA), intermediate (IA) and total (TA) alkalinity (Jantsch and Mattiasson, 2004). 
Table 1. Operational conditions for the trial

\begin{tabular}{ccccccc}
\hline \multirow{2}{*}{ Digester } & \multicolumn{2}{c}{ Cattle slurry } & \multicolumn{2}{c}{ Maize } & Water & Retention time \\
\cline { 2 - 7 } & $\mathrm{g} \mathrm{VS}^{-1}$ day $^{-1}$ & $\mathrm{~g} \mathrm{WW}_{\text {day }}{ }^{-1}$ & $\mathrm{~g} \mathrm{VS} \mathrm{l}^{-1}$ day $^{-1}$ & $\mathrm{~g} \mathrm{WW} \mathrm{day}^{-1}$ & $\mathrm{~g} \mathrm{day}^{-1}$ & days \\
1\&2 & 1.5 & 117 & 1.5 & 18.7 & 0 & 29 \\
$3 \& 4$ & 2.5 & 156 & 2.0 & 24.9 & 0 & 22 \\
$5 \& 6$ & 2.5 & 195 & 2.5 & 31.1 & 0 & 18 \\
$7 \& 8$ & 3.0 & 273 & 3.0 & 37.3 & 0 & 15 \\
Mono-digestion & & & & & & \\
$9 \& 10$ & 1.5 & 117 & 0 & 0 & 18.7 & 29 \\
& 2.0 & 156 & 0 & 0 & 24.9 & 22 \\
& 2.5 & 195 & 0 & 0 & 31.1 & 18 \\
$11 \& 12$ & 3.0 & 273 & 0 & 0 & 37.3 & 15 \\
& 0 & 0 & 1.5 & 18.7 & 117 & 29 \\
& 0 & 0 & 2.0 & 24.9 & 156 & 22 \\
& 0 & 0 & 2.5 & 31.1 & 195 & 18 \\
\hline
\end{tabular}

WW = wet weight

\section{RESULTS AND DISCUSSION}

Feedstock characteristics. The feedstock characteristics were: VS (\% WW) 32.24 and 4.98; TS (\%WW) 33.7 and 7.68; $\mathrm{pH} 4.0$ and 6.7; TKN ( $\left.\mathrm{g} \mathrm{l}^{-1}\right) 4.82$ and 3.06; $\mathrm{NH}_{3}\left(\mathrm{~g} \mathrm{l}^{-1}\right) 0.69$ and 1.19; VFA $\left(\mathrm{mg} \mathrm{l}^{-1}\right)$ not measured and 2938 , for maize and cattle slurry respectively.

\section{Mono-digestion}

Methane production in the mono-digestion trial is shown in Figure 1. The cattle slurry ran at an OLR of $3 \mathrm{~g} \mathrm{VS}^{-1}$ day $^{-1}$ for one retention time only due to lack of material: it was decided not to extend the trial with a new batch of slurry as previous results (not reported here) clearly showed that performance could vary significantly between different batches.

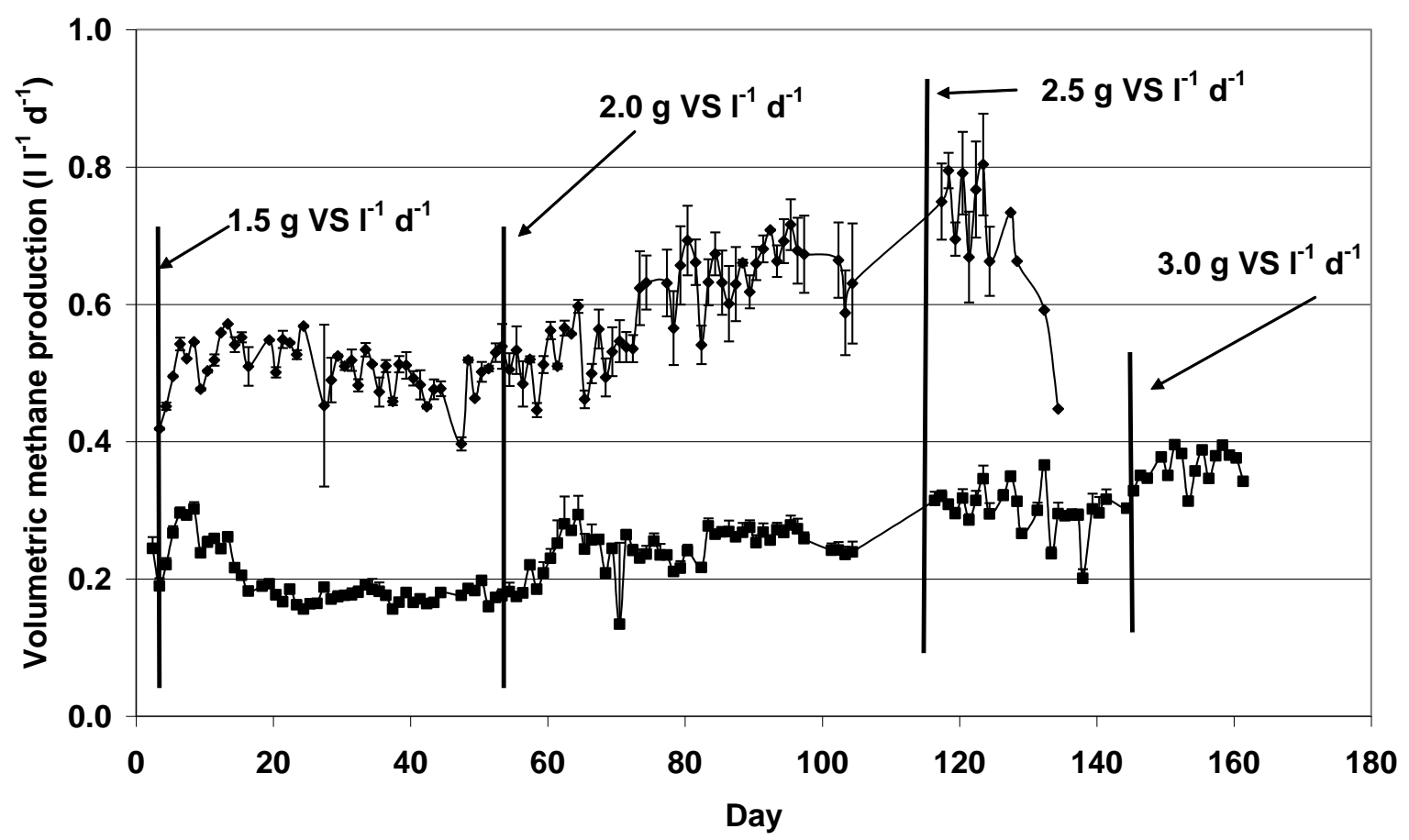

Figure 1: Average daily volumetric methane yield of each digester pair produced at all OLRs tested for both maize $(\boldsymbol{\square})$ and the cattle slurry $(\diamond)$. The lines represent increments in OLR.

At the $1.5 \mathrm{~g} \mathrm{VS}^{-1}$ day $^{-1}$ OLR specific methane production appeared constant for both substrates, with maize giving the greatest volumetric methane yield. The volumetric methane yield of the cattle slurry increased up to the highest OLR, in agreement with Linke et al. 
(1997) who found that 15 days was an adequate retention time for methanisation of this substrate. Maize was successfully digested at OLRs of 1.5 and $2 \mathrm{~g} \mathrm{VS}^{-1}$ day $^{-1}$ producing volumetric methane yields of 0.51 and $0.641^{-1} \mathrm{l}^{-1}$ day $^{-1}$, respectively. Within 6 days of increasing the load to $2.5 \mathrm{~g} \mathrm{VS}^{-1}$ day $^{-1}$, however, methane production declined sharply and $\mathrm{pH}$ fell to below 5 indicating failure of the digestion.

Increasing the OLR reduced the specific methane yield for both substrates. For cattle slurry the reduction was low, with a difference of only $0.0151 \mathrm{CH}_{4} \mathrm{~g}^{-1} \mathrm{VS}$ between the 1.5 and $3 \mathrm{~g}$ $\mathrm{VS}^{-1}$ day $^{-1}$ OLRs, corresponding to $11 \%$ of the higher value. For the maize, the difference between specific yield at the two successful loadings was greater at $0.021 \mathrm{CH}_{4} \mathrm{~g}^{-1} \mathrm{VS}$, although this is only a $6 \%$ change in the larger value. The failure of the maize digestion at a loading of $2.5 \mathrm{~g} \mathrm{VS}^{-1}$ day $^{-1}$ could be due to the short retention time of 18 days, which would lead to rapid washout of alkalinity and nutrients, and could prove more detrimental to the digestion of maize compared to cattle slurry where these are more plentiful. As the retention time decreased from 29 to 18 days both alkalinity and ammonia declined in the maize digesters, by 78 and $95 \%$ respectively.

\section{Co-digestion}

In the first 25 days of the trial, biogas production increased at all OLRs; at the $5 \mathrm{~g} \mathrm{VS}^{-1}$ day $^{-1}$ loading an increase from $0.581^{-1}$ day $^{-1}$ at day 5 to $0.9511^{-1}$ day $^{-1}$ at day 24 was observed. This could have been due to the quality of inoculum used. After this, gas production was stable; average volumetric and specific methane productions for the final 20 days are shown in Figure 2a.

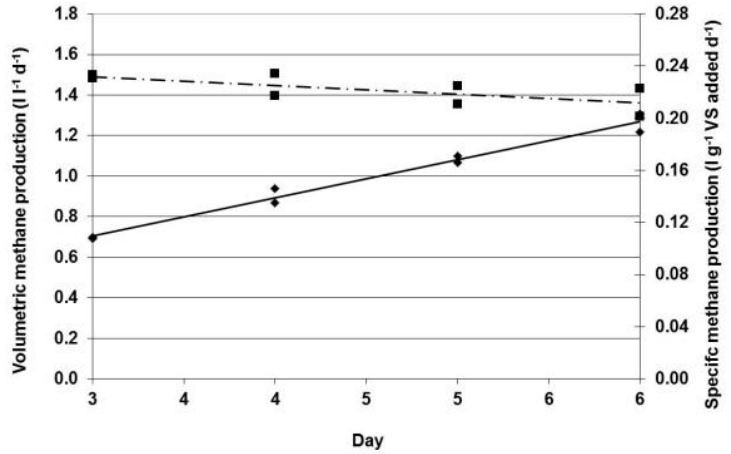

a) Volumetric $(\diamond)$ and specific $(\boldsymbol{\square})$ methane production at each OLR (average values from final 20 days of trial)

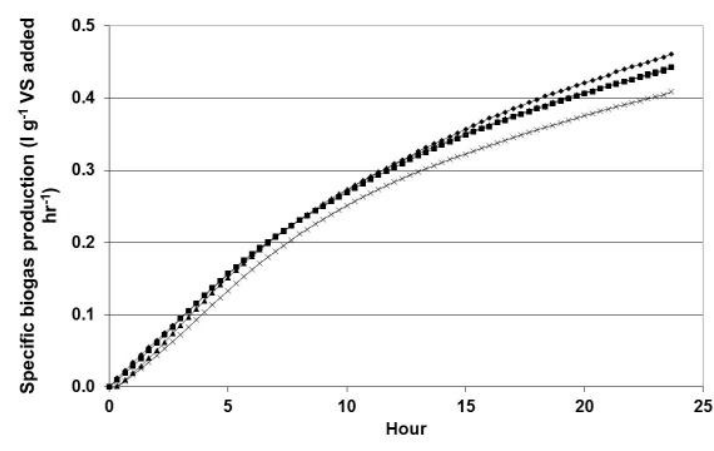

b) Average specific biogas yield in all conditions tested during a 24-hour period at day 60: $3 \mathrm{~g} \mathrm{VS} \mathrm{l}^{-1} \mathrm{~d}^{-1}$ $(\diamond), 4 \mathrm{~g} \mathrm{VS} \mathrm{l}^{-1} \mathrm{~d}^{-1},(\boldsymbol{\bullet}), 5 \mathrm{~g} \mathrm{VS}^{-1} \mathrm{~d}^{-1}(\boldsymbol{\Delta})$ and $6 \mathrm{~g} \mathrm{VS}^{-1}$ $\mathrm{d}^{-1}(\mathrm{X})$

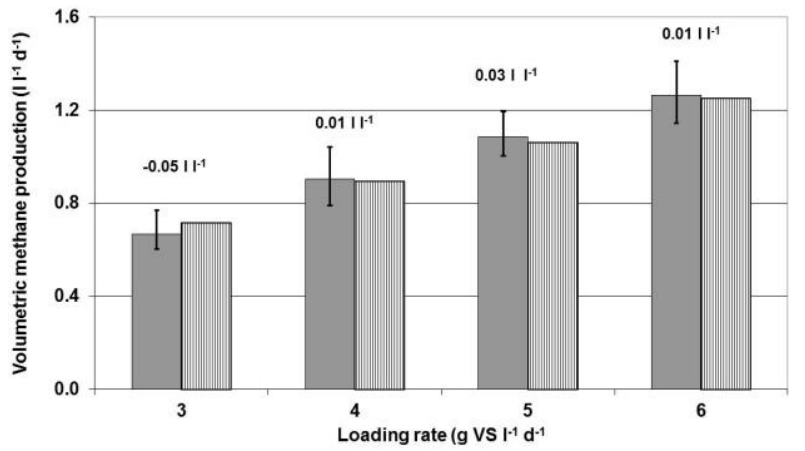

c) Average volumetric methane production of each digester pair (filled bars) and yield calculated from combined methane potential of maize and cattle slurry (striped bars), showing numerical difference and range.

Figure 2. Biogas and methane production rates 
Volumetric methane production showed an approximately linear relationship with loading, of $0.2011^{-1}$ per $\mathrm{g} \mathrm{VS}$ added $\mathrm{l}^{-1} \mathrm{day}^{-1}\left(\mathrm{R}^{2}=0.993\right)$; although the improvement decreased slightly as the OLR increased. Increasing the OLR from 5 to $6 \mathrm{~g} \mathrm{VS}^{-1}$ day $^{-1}$ only increased production by $0.18 \mathrm{l} \mathrm{l}^{-1}$ day $^{-1}$ compared to $0.24 \mathrm{l} \mathrm{l}^{-1} \mathrm{day}^{-1}$ for an increase from 3 to $4 \mathrm{~g} \mathrm{VS} \mathrm{l}^{-1}$ day $^{-1}$. Nevertheless the increase in OLR from 3 to $6 \mathrm{~g} \mathrm{VS}^{-1}$ day $^{-1}$ almost doubled volumetric methane production while still maintaining the specific methane yield, despite a 14-day reduction in retention time to 15 days. Research by Lehtomäki et al. (2006) on co-digestion of cattle slurry with a range of energy crops, grass silage, sugar beet and oat straw, found that increasing the loading resulted in a decline in specific biogas yield as the OLR increased from 3 to $4 \mathrm{~g} \mathrm{VS}^{-1}$ day $^{-1}$. This was also shown by Mähnert et al. (2007) where a decline was shown as the load increased from 1 to $4 \mathrm{~g} \mathrm{VS} \mathrm{l}^{-1} \mathrm{~d}^{-1}$ during the co-digestion of cattle slurry and maize. Specific methane yields in Figure 2a declined by $0.02 \mathrm{l} \mathrm{g}^{-1} \mathrm{VS}$ compared to an increase in the volumetric methane of $0.5911^{-1}$ day $^{-1}$ as the OLR increased from 3 to $6 \mathrm{~g} \mathrm{VS}^{-}$ ${ }^{1}$ day $^{-1}$. This very small reduction in specific methane yield suggests that, increasing the load above $3 \mathrm{~g} \mathrm{VS}^{-1}$ day $^{-1}$ may be worthwhile in terms of the total methane production.

Daily biogas production for day 60 of the co-digestion trial, in the steady state period, is shown in Figure 2b. As can be seen, there was little difference in the rate of production at all OLRs, indicating no overloading was occurring. All the digesters displayed a higher rate of production of $0.0301 \mathrm{~g}^{-1} \mathrm{VS}$ in the initial 8 hours after feeding compared to $0.012 \mathrm{~g} \mathrm{~g}^{-1} \mathrm{VS}$ over the latter part of the daily feed cycle.

Table 2 compares gas production in the co-digestion trial and mono-digestion trials, and it can be seen that the addition of an equal quantity of maize to the cattle slurry caused the volumetric methane yield at all cattle slurry loads to increase by over $200 \%$. This demonstrates that large quantities of maize are not required to increase the volumetric productivity of the digester: a $1.5 \mathrm{~g} \mathrm{VS}^{-1}$ day $^{-1}$ maize addition to a $1.5 \mathrm{~g} \mathrm{VS} \mathrm{l}^{-1}$ day $^{-1}$ cattle slurry load resulted in an increase of $219 \%$. The maximum load tested in the cattle slurry mono-digestion trial could be doubled by adding an equal quantity of maize without a decline in the specific methane yield.

Table 2. Improvement in volumetric methane yield from addition of an equal quantity of maize to the cattle slurry at all cattle slurry loads tested.

\begin{tabular}{|c|c|c|c|c|}
\hline \multirow[t]{2}{*}{$\begin{array}{l}\text { Cattle slurry loading rate } \\
\quad\left(\mathrm{g} \mathrm{VS}^{-1} \mathrm{day}^{-1}\right)\end{array}$} & \multicolumn{2}{|c|}{$\begin{array}{l}\text { Volumetric methane yield } \\
\left(1 \mathrm{l}^{-1} \mathrm{day}^{-1}\right)\end{array}$} & \multicolumn{2}{|c|}{ Improvement } \\
\hline & Mono-digestion & $\begin{array}{l}\text { With equal addition } \\
\text { of maize }\end{array}$ & $1 l^{-1}$ day $^{-1}$ & $\%$ \\
\hline 1.5 & 0.21 & 0.67 & 0.46 & 219 \\
\hline 2.0 & 0.25 & 0.90 & 0.65 & 260 \\
\hline 2.5 & 0.30 & 1.09 & 0.79 & 263 \\
\hline 3.0 & 0.36 & 1.26 & 0.90 & 250 \\
\hline
\end{tabular}

Examination of the results also indicated that the methane yields in the co-digestion trials were approximately equal to those calculated from the methane potential of the individual substrates, as shown in Figure 2c. A number of studies on co-digestion of crops with cattle slurry have suggested that synergy may occur between substrates (Machmuller et al., 2007, Lehtomäki et al., 2006). Work by Mähnert et al., (2006), however, that it is possible to calculate the biogas yield of a co-digestion mix by the sum of the individual substrates, and the results in Figure 2c support this.

The addition of cattle slurry allowed maize digestion at loadings of 2.5 and $3 \mathrm{~g} \mathrm{VS}^{-1} \mathrm{day}^{-1}$, which failed under mono-digestion conditions. The results from the mono-trial indicated that the main reason for the failure of maize at higher loadings was the washout of alkalinity and 
ammonia when water was added in place of cattle slurry. This highlights the importance of the ammonia and alkalinity that cattle slurry brings to the system, especially at high loads and short retention times. A similar result was reported by Mähnert et al., (2006) who found that maize could only be digested at loads greater that $3 \mathrm{~g} \mathrm{VS}^{-1}$ day $^{-1}$ when combined with cattle slurry. The importance of the buffering capacity of cattle slurry was noted by Angelidaki and Ellegaard (2003) and has been shown in the digestion of food waste (Alvarez and Lindén, 2008). This benefit was also highlighted when the stability of OFMSW digestion was improved during the initial stages of the process (Capela et al., 2007).

Increasing the OLR to $6 \mathrm{~g} \mathrm{VS} \mathrm{l}^{-1}$ day $^{-1}$ increased the volumetric yield but it appears this load is not optimal: the increase produced the greatest decline in the average specific methane yield and thus loss of the methane potential of the maize, with the specific methane yield attributable to the maize reducing from 0.33 to $0.30 \mathrm{~g}^{-1} \mathrm{VS}$ maize. In the 3 to $5 \mathrm{~g} \mathrm{VS} \mathrm{l}^{-1} \mathrm{day}^{-1}$ loading range specific methane yields remained constant. Considering the corresponding increase in volumetric methane yield it can be suggested that the optimal load is 4 or $5 \mathrm{~g} \mathrm{VS}^{-}$ ${ }^{1}$ day $^{-1}$. It could be argued that the $5 \mathrm{~g} \mathrm{VS} \mathrm{l}^{-1}$ day $^{-1}$ OLR is best, based on the volumetric yield; a disadvantage of this loading rate, however, is that it leads to a low retention time and so to a reduction in the amount of methane attributable to the maize. In addition to reducing the efficiency of energy recovery from the maize, the higher OLR will require the diversion of a greater quantity of maize from food or fodder to energy production.

Ammonia and alkalinity appeared to play an important role in the digestion of maize at short retention times and this can be seen by comparing the mono-digestion of maize at the $2.5 \mathrm{~g}$ $\mathrm{VS}^{-1}$ day $^{-1}$ load with the co-digestion trial at a load of $5 \mathrm{~g} \mathrm{VS}^{-1}$ day $^{-1}$. Replacing the water with cattle slurry significantly increased the ammonia concentration from 0.09 to $1.14 \mathrm{~g} \mathrm{l}^{-1}$ and therefore the alkalinity of the system indicating that maize can be digested at loads of 2.5 $\mathrm{g} \mathrm{VS}^{-1} \mathrm{~d}^{-1}$ and short retention times if there is adequate buffering

The second output of anaerobic digestion is the digestate. Digestate characteristics from the co-digestion trial are summarised in Table 3. Initially digestate VFA concentrations were over $1500 \mathrm{mg} \mathrm{l}^{-1}$, and stability was not achieved until day 24, after which the concentration remained below $200 \mathrm{mg} \mathrm{l}^{-1}$. This corresponded to a recovery in volumetric methane production during this period. Apart from at the lowest OLR, the digestate from co-digestion with maize at a 50:50 VS ratio has a higher TS content than the 7.68\% TS in the raw cattle slurry. Increasing the OLR gave a slight increase in digestate TS and VS, with the TS concentration at the highest loading $\sim 1 \%$ higher than the lowest. This increase in TS could have a negative impact on use of the digestate as a fertiliser by reducing the rate of soil infiltration (Smith et al., 2001a; Misselbrook et al., 2005).

Table 3. Digestate characteristics at all loading rates (average for last 20 days of trial)

\begin{tabular}{llrrrr}
\hline OLR $\left(\mathrm{g} \mathrm{VS} \mathrm{l}^{-1}\right.$ day $\left.^{-1}\right)$ & Unit & $\mathbf{3}$ & $\mathbf{4}$ & $\mathbf{5}$ & $\mathbf{6}$ \\
\hline $\mathrm{pH}$ & & 7.4 & 7.3 & 7.2 & 7.2 \\
$\mathrm{TS}$ & \%WW & 7.4 & 7.8 & 8.3 & 8.4 \\
$\mathrm{VS}$ & \%WW & 5.0 & 5.2 & 5.4 & 5.5 \\
VS destruction & $\%$ & 55.2 & 45.6 & 43.1 & 41.5 \\
$\mathrm{TKN}$ & $\mathrm{g} \mathrm{l}^{-1}$ & 3.4 & 3.3 & 3.3 & 3.3 \\
$\mathrm{NH}_{3}$ & $\mathrm{~g} \mathrm{l}^{-1}$ & 1.3 & 1.2 & 1.1 & 1.0 \\
\% of TKN & & 37 & 36 & 32 & 31 \\
Total Alkalinity & $\mathrm{g} \mathrm{CaCO}_{2} 1^{-1}$ & 10.7 & 9.8 & 9.4 & 9.1 \\
IA:PA & & 0.38 & 0.34 & 0.35 & 0.39 \\
VFA & $\mathrm{mg} \mathrm{l}^{-1}$ & 203 & 165 & 173 & 170 \\
\hline
\end{tabular}


The application of cattle slurry to land causes ammonia emissions and Clemens et al., (2006) showed this was associated with the increase in ammonia occurring upon digestion. The results in Table 3 show that increasing the OLR led to a decline in digestate ammonia concentration from 1.3 to $1.0 \mathrm{~g} \mathrm{l}^{-1}$. This suggests that increasing the load could help to reduce ammonia emissions; however, this reduction is cancelled out by the increase in the quantity of digestate removed daily at the higher loads. This results in larger quantities of ammonia leaving the digester, e.g. 0.16 and $0.26 \mathrm{~g} \mathrm{day}^{-1}$ for the 3 and $6 \mathrm{~g} \mathrm{VS}^{-1}$ day $^{-1}$ loads respectively. The above results may be of use in an assessment to determine the full environmental benefits and impacts of the digestion process.

\section{CONCLUSIONS}

The co-digestion of cattle slurry and maize was shown to be possible at all loading rates tested with volumetric methane production increasing as the loading increased but no significant reduction in specific methane yield. The addition of cattle slurry to maize was shown to be beneficial at higher loadings as it allowed maize to be successfully digested at retention times of 18 and 15 days; this was shown not to be possible when maize was digested alone at the same loading .

Comparison between the mono and co-digestion trials indicated that the production of methane from the co-digestion mix could be calculated by combining the methane yields of the individual substrates. The comparison also showed that the introduction of maize to digestion of cattle slurry has a pronounced effect on the volumetric methane yield; doubling the OLR for cattle slurry alone by addition of an equal quantity of maize on a VS basis gave an increase in volumetric methane yield of $250 \%$. This was achieved in all cases without a great loss of the methane potential of the maize despite a reduction in the retention time to 15 days at the highest loading rate. It was also shown that it was not necessary to introduce large quantities of maize to the digestion of cattle slurry to produce an improvement in the biogas production: an addition of $1.5 \mathrm{~g} \mathrm{VS}^{-1} \mathrm{~d}^{-1}$ to an equal load of cattle slurry increased the volumetric methane yield by $219 \%$.

\section{References}

Alvarez, R. \& Lidén, G. (2008). Semi-continuous co-digestion of solid slaughterhouse waste, manure, and fruit and vegetable waste. Renewable Energy, 33, 726-734.

Angelidaki, I. \& Ellegaard, L. (2003). Co-digestion of manure and organic wastes in centralized biogas plants: status and future trends. Applied Biochemistry and Biotechnology, 109, 95-106.

APHA (2005). Standard Methods for the Examination of Water and Wastewater, American Public Health Association, American Water Works Association, Water Environment Federation.

Banks, C. J. \& Zhang, Y. (2010). Technical report for Defra 'Optimising inputs and outputs from anaerobic digestion processes' http://randd.defra.gov.uk/Document.aspx?Document=WR0212_8889_TRP.pdf 4/04/2010

Callaghan, F. J., Wase, D. A. J., Thayanithy, K. \& Forster, C. F. (1998). An examination of the continuous anaerobic codigestion of cattle slurry and fish offal. Institution of chemical engineers, 76 part B, 224-228.

Callaghan, F. J., Wase, D. A. J., Thayanithy, K. \& Forster, C. F. (1999). Co-digestion of waste organic solids: batch studies. Bioresource Technology, 67, 117-122.

Capela, I., Rodrigues, A., Silva, F., Nadais, H. \& Arroja, L. (2007). Impact of industrial sludge and cattle manure on anaerobic digestion of the OFMSW under mesophilic conditions. Biomass and Bioenergy, In Press, Corrected Proof.

Clemens, J., Trimborn, M., Weiland, P. \& Amon, B. (2006). Mitigation of greenhouse gas emissions by anaerobic digestion of cattle slurry. Agriculture, Ecosystems \& Environment, 112, 171-177.

Cornell, M., Banks, C. J. \& Heaven, S. (2008). Impact of the addition of maize on the anaerobic digestion of cattle slurry (Article in preparation). The University of Southampton.

Gonzalez-Gil, G., Seghezzo, L., Lettinga, S. \& Kleerebezem, R. (2001). Kinetics and mass-transfer phenomena in anaerobic granular sludge. Biotechnology and Bioengineering, 73, 125-134.

Holm-Nielsen, J. B. (2007). The future of biogas in Europe: Visions and Targets 2020. European Biogas Workshop and Study Trip. University of Southern Denmark, Esbjerg, Denmark.

Jantsch, T. G. \& Mattiasson, B. (2004). An automated spectrophotometric system for monitoring buffer capacity in anaerobic digestion processes. Water Research, 38, 3645-3650.

Lehtomäki, A., Huttunen, S. \& Rintala, J. A. (2006). Laboratory investigations on co-digestion of energy crops and crop 
residues with cow manure for methane production. Resources and Recycling.

Linke, B. (1997). A model for anaerobic digestion of animal waste slurries. Environmental Technology, 18, 849-854.

Machmüller, A., R., H., Kryvoruchko, V. \& Amon, T. (2007). Biogas production from energy crops produced on sustainable crop rotations. Vienna, Austria, University of Natural Resources and Applied Life Sciences.

Mähnert, A. \& Linke, B. (2006). Biogas production from energy crops in Germany. National workshop with foreign participation "updating and perspective for the biogas production in Cuba" . Sancti Spiritus, Cuba.

Misselbrook, T. H., Nicholson, F. A. \& Chambers, B. J. (2005). Predicting ammonia losses following the application of livestock manure to land. Bioresource Technology, 96, 159-168.

Smith, K. A., Jackson, D. R. \& Pepper, T. J. (2001a). Nutrient losses by surface run-off following the application of organic manures to arable land. 1. Nitrogen. Environmental Pollution, 112, 41-51.

Weiland, P. (2006). Biomass Digestion in Agriculture: A Successful Pathway for the Energy Production and Waste Treatment in Germany. Engineering in Life Sciences, 6, 302-309.

Walker, M., Zhang, Y., Heaven, S., Banks C.J. (2009) Potential errors in the quantitative evaluation of biogas production in anaerobic digestion processes. Bioresource Technology, 100(24), 6339-6346. 